\title{
146. Amino Acid Content of Einkorn Wheat Chlorophyll Mutants (Preliminary Report)*)
}

\author{
By Tarô FujII and Yukio ONo \\ National Institute of Genetics, Misima, Japan \\ (Comm. by H. KinARA, M.J.A., Nov. 12, 1960)
}

It is well known that amino acids play an important role in the synthesis of proteins. Their content sometimes varies by the physiological or genetical conditions of the materials and even by irradiation. According to Mericle and Mericle (1959), X-irradiation may have not only an overall depressing effect on the total amino acid content, but it seems to have also a differential effect on the individual amino acids. On the other hand, the chlorophyll content is strongly affected by the protein content (Holmgren, 1956; Schwarze, 1952). Holmgren also observed a higher amount of free amino acids in albina than in normal green barley seedlings, which indicates a block in the synthesis of the plastid protein. The relations between chlorophyll content and amino acid content are very interesting from the physiological and genetical view points. They have been examined by the present authors in the chlorophyll mutants of einkorn wheat and the results are reported in this preliminary report.

Materials. Albina, chlorina, xantha, and virido-albina mutants of Triticum monococcum L. var. flavescens Körn. were used in this study. They were obtained as simple recessive mutants in the $\mathrm{X}_{2}$ generation from irradiated seeds. Albina mutants have no chlorophyll and die about one month after germination. The chlorina mutant is uniformly light green and remains yellowish green from seedling stage to maturity. Its chlorophyll content is about 50 per cent of that of the normals (Fujii, 1955). The xantha mutant is greenish yellow and, like albina, cannot grow. In the virido-albina mutant the leaf-sheath and base of leaf-blade are white, while the leaf tip is light green in the seedling stage. Its viability is poor, but it recoveres the chlorophyll content up to normal when placed in the greenhouse or in the phytotron (air conditioned greenhouse) and produced ripe seeds. The chlorophyll content of this mutant is about 20 per cent of that of the normals (Fujii, 1956).

Results. 1) Amount of free amino acid. Seeds of normals and several mutants were sown on sand without fertilizer. Leaves were

*) Contributions from the National Institute of Genetics, Japan, No. 332. 
collected from the seedlings and the free amino acid component was extracted with 75 per cent ethanol at room temperature about 15 days after sowing. Fresh leaves of the same weight were prepared from each strain and were extracted with the same quantity of the solvent. The extracted components were concentrated on a water bath and the paperchromatographic analysis was used for the separation of amino acids. The aliquots of the concentrated components were spotted on Tôyô No. 50 filter paper, and irrigated with butanol/acetic acid/water $(4: 1: 2)$ in one direction, and then with phenol/water $(7: 3)$ in two directions. The developed papers were dried and their chromatograms were sprayed with 0.1 per cent aqueous solution of ninhidrine whereupon several amino acids appeared as colored spots. Their kinds were identified by their $\mathrm{Rf}$-values with the authentic specimens.

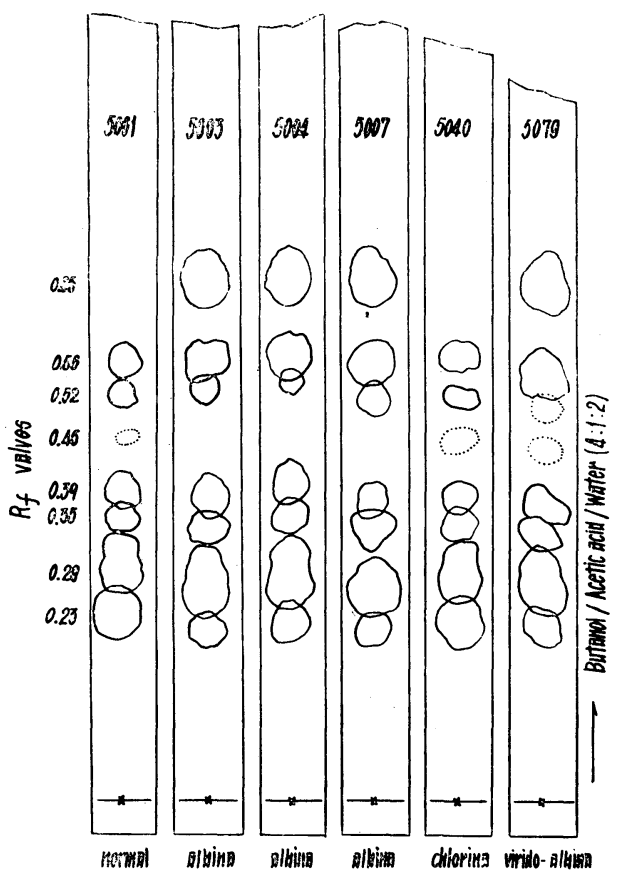

Fig. 1. Free amino acids in normals and mutants on one-dimensional paperchromatogram

Some typical chromatograms are shown in Fig. 1 for one dimensional development. Normal and chlorina showed seven spots of similar size, respectively. Three albinas showed the seven spots of similar size but the fifth spot from the bottom was absent and an eighth spot was newly observed. Virido-albina had the same spots as normals and chlorina and showed an eighth spot like albina.

As shown in Fig. 2, nine kinds of spots were observed by twodimensional chromatography. Seven showed the presence of aspartic 

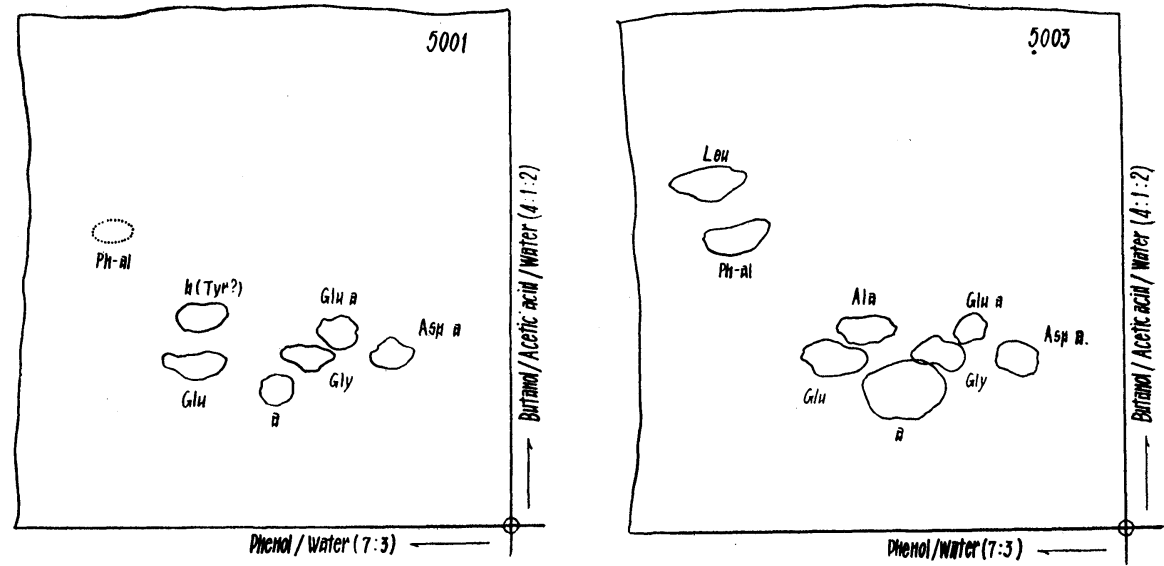

Fig. 2. Free amino acids on two-dimensional paperchromatogram
a, normal
b, albina-5003

acid, glutamic acid, glycine, alanine, glutamine, phenyl alanine, and leucine. And two other spots were also observed, namely an unidentified spot $a$ and a spot $b$, indicating probably tyrosine. The experiments were repeated from two to six times, and relative amounts of each amino acid are shown in Table I. Aspartic acid, glutamic acid, and glycine were present in similar amounts in all strains and glutamine, phenyl alanine, and spot a were in most of albinas larger than in normals and chlorina. Remarkable differences were observed in the amounts of alanine, leucine, and spot $b$, namely alanine and leucine were not observed either in normals or chlorina, while they were contained in all albinas and virido-albina. The spot $\mathrm{b}$ was absent or only its trace was detected in most of albinas. Glutamine was absent only in xantha, while it was found in an appreciable

Table I. Relative amount of free amino acids in chlorophyll mutants

\begin{tabular}{|c|c|c|c|c|c|c|c|c|c|c|}
\hline $\begin{array}{c}\text { Charac- } \\
\text { ter }\end{array}$ & Strain & $\begin{array}{c}\text { Aspar- } \\
\text { tic } \\
\text { acid }\end{array}$ & $\begin{array}{l}\text { Glu- } \\
\text { tamic } \\
\text { acid }\end{array}$ & $\begin{array}{l}\text { Gly- } \\
\text { cine }\end{array}$ & $\begin{array}{l}\text { Ala- } \\
\text { nine }\end{array}$ & $\begin{array}{l}\text { Gluta- } \\
\text { mine }\end{array}$ & $\begin{array}{l}\text { Phenyl } \\
\text { alanine }\end{array}$ & $\begin{array}{l}\text { Leu- } \\
\text { cine }\end{array}$ & $\begin{array}{c}\text { Spot } \\
\mathbf{a}\end{array}$ & $\begin{array}{c}\text { Spot b } \\
\text { (tyro- } \\
\text { sine) }\end{array}$ \\
\hline Normal & 5001 & + & + & + & - & + & \pm & - & + & + \\
\hline $\begin{array}{c}\text { Albina } \\
\text {," } \\
\text { ", } \\
\text { ", } \\
\text { ", } \\
\text { ", } \\
\text {," }\end{array}$ & $\begin{array}{l}5002 \\
5003 \\
5004 \\
5005 \\
5006 \\
5007 \\
5009 \\
5011 \\
5012\end{array}$ & $\begin{array}{l}+ \\
+ \\
+ \\
+ \\
+ \\
+ \\
+ \\
+ \\
+\end{array}$ & $\begin{array}{l}+ \\
+ \\
+ \\
+ \\
+ \\
+ \\
+ \\
+ \\
+\end{array}$ & $\begin{array}{l}+ \\
+ \\
+ \\
+ \\
+ \\
+ \\
+ \\
+ \\
+\end{array}$ & $\begin{array}{l}+ \\
+ \\
+ \\
\pm \\
\pm \\
\pm \\
+ \\
+ \\
+\end{array}$ & $\begin{array}{l}\text { H } \\
\text { \# } \\
+ \\
+ \\
+ \\
+ \\
+ \\
+ \\
+\end{array}$ & $\begin{array}{l}+ \\
+ \\
+ \\
+ \\
+ \\
+ \\
+ \\
+ \\
+\end{array}$ & $\begin{array}{l}\text { \# } \\
\text { \# } \\
+ \\
+ \\
+ \\
+ \\
+ \\
+\end{array}$ & 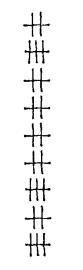 & $\begin{array}{l}+ \\
- \\
- \\
\pm \\
+ \\
\pm \\
\pm \\
\pm \\
\pm\end{array}$ \\
\hline Xantha & 5013 & + & + & + & + & - & H & + & $H$ & + \\
\hline Chlorina & 5040 & + & + & + & - & + & \pm & - & + & + \\
\hline $\begin{array}{l}\text { Virido- } \\
\quad \text { albina }\end{array}$ & 5079 & + & + & $H$ & + & H & + & + & + & + \\
\hline
\end{tabular}


amount in normals and all other mutants. Among albina strains there was a small difference in the amount of each kind of amino acid. For instance, spot b was clearly detectable in 5002 and 5006, but it was absent or its trace only in the other seven albinas. As to those differences among albinas further study must be carried on.

2) Amount of amino-nitrogen $\left(\mathrm{NH}_{2}-\mathrm{N}\right)$. Fresh leaves from normals and mutant strains were extracted with 50 per cent ethanol. The amount of amino-nitrogen was measured by Vanslyke's method; it corresponded to the total amount of free amino acids. Some of these experiments were repeated two or three times and the results are shown in Table II. The amounts varied by experiment, probably due to the difference in the growth stage of the seedlings. But albina and virido-albina showed about 1.5-2 times larger amino acid amounts than normals and chlorina. And the amount found in xantha was about half of that of the normals. The results of these experiments are in good accord with the paperchromatographic observations and also showed little differences in amino-nitrogen amounts among albina strains. These facts will be dealt in detail in a future communication.

Table II. Amount of amino-nitrogen in chlorophyll mutants

\begin{tabular}{|c|c|c|c|c|c|}
\hline \multirow{2}{*}{ Character } & \multirow{2}{*}{ Strain } & \multirow{2}{*}{$\begin{array}{c}\text { Fresh weight } \\
\text { of leaves } \\
\text { (mg) }\end{array}$} & \multirow{2}{*}{$\begin{array}{l}\text { Amount } \\
\text { of solvent } \\
(\mathrm{ml})\end{array}$} & \multicolumn{2}{|c|}{ Amount of amino-nitrogen } \\
\hline & & & & $\mathrm{N}_{2}$ gas $/ 0.5 \mathrm{ml}$ & Index \\
\hline $\begin{array}{l}\text { Normal } \\
\text { Albina }\end{array}$ & $\begin{array}{l}5001 \\
5003\end{array}$ & $\begin{array}{l}230 \\
,,\end{array}$ & $\begin{array}{l}2 \\
,,\end{array}$ & $\begin{array}{l}0.38 \\
0.91\end{array}$ & $\begin{array}{l}1 \\
2.39\end{array}$ \\
\hline $\begin{array}{l}\text { Normal } \\
\text { Albina } \\
\quad, ' \\
\text { Xantha } \\
\text { Chlorina }\end{array}$ & $\begin{array}{l}5001 \\
5011 \\
5012 \\
5013 \\
5040\end{array}$ & $\begin{array}{l}800 \\
250 \\
800 \\
500 \\
,,\end{array}$ & $\begin{array}{l}6 \\
2 \\
6 \\
4 \\
,,\end{array}$ & $\begin{array}{l}1.05 \\
1.46 \\
1.65 \\
0.55 \\
1.17\end{array}$ & $\begin{array}{l}1 \\
1.39 \\
1.57 \\
0.52 \\
1.11\end{array}$ \\
\hline $\begin{array}{l}\text { Normal } \\
\text { Albina } \\
\quad,,\end{array}$ & $\begin{array}{l}5001 \\
5003 \\
5004 \\
5009\end{array}$ & $\begin{array}{c}1000 \\
,, \\
, "\end{array}$ & $\begin{array}{l},, \\
, "\end{array}$ & $\begin{array}{l}0.86 \\
1.25 \\
1.35 \\
1.72\end{array}$ & $\begin{array}{l}1 \\
1.45 \\
1.57 \\
2.0\end{array}$ \\
\hline $\begin{array}{l}\text { Normal } \\
\text { Albina } \\
\text { Virido-albina }\end{array}$ & $\begin{array}{l}5001 \\
5012 \\
5079\end{array}$ & $\begin{array}{l}650 \\
,,\end{array}$ & ,, & $\begin{array}{l}1.26 \\
1.37 \\
1.95\end{array}$ & $\begin{array}{l}1 . \\
1.09 \\
1.54\end{array}$ \\
\hline
\end{tabular}

Discussion. Differences in free amino acid contents between normals and several chlorophyll mutants were examined on the basis of paperchromatography and quantitative analysis of amino-nitrogen. As to the total amino acids, a larger amount was observed in albina and virido-albina seedlings than in the normals and chlorina. Alanine and leucine were not observed in the latter two, though they were contained in albina and virido-albina. Spot b (tyrosine?) was absent or only a trace was found in most of albinas and glutamine did not occur in xantha. 
Seedlings of cereals are immediately after germination supplied with materials laid down in the endosperm which will contribute correlated enzymes for photosynthesis to chlorophyll synthesis (Edelman et al., 1959). Photosynthesis and conversion of its products occur after the development of chlorophyll in the leaves of the seedlings. The products of photosynthesis are biochemical energy and carbohydrates, which in turn affect all other assimilatory processes and a low photosynthetic activity is supposed to be connected with a small amount of chlorophyll present (Tolbert, 1957). For instance, when chlorophyll deficiency is severe, the protein content is also low (Schwarze, 1952). Similar results were also observed by Holmgren (1956), namely the protein content in albina mutant of barley was about 30 per cent of that of the normals. Thus, when the supply from endosperm to leaves is exhausted in albina, the plants must die. Since they have no chlorophyll owing to a block of a step in chlorophyll synthesis, they do not have the ability of photosynthesis. In this case materials supplied by the endosperm must accumulate in albina leaves. Large amounts of free amino acids seem to derive from this source and the results of our experiment are in good accord with the findings in albina barley mutant (Holmgren, 1956).

Amount and kinds of amino acids in chlorina showed a similar tendency to that of the normals, while their chlorophyll content was about 50 per cent of that of the normals and recovery did not take place (Fujii, 1955). On the other hand, amount and kinds of amino acid in virido-albina showed a similar tendency to that of albina, while its chlorophyll content recovered to the normal level (Fujii, 1956). In our experiment, the amount of amino acids was examined in the early seedling stage. Therefore, the detected components were mainly derived from materials supplied by the endosperm. These materials are converted to other higher compounds owing to the activity of chlorophyll in normals and chlorina. The chlorina mutant has photosynthetic ability and relatively high survival rate and fertility. The virido-albina mutant has only 20 per cent of normal chlorophyll content in the seedling stage (Fujii, 1956). The materials supplied by the endosperm may not be easily converted to higher compounds in the presence of such a small amount of chlorophyll, and the amino acid content in this mutant is the same as in albina.

From our experiments, it is concluded that the amount of free amino acids in an early seedling stage is controlled by the chlorophyll content and that amino acids are not related either to recovery or non-recovery of chlorophyll content, as was observed in virido-albina and chlorina. Amino acid or amino-nitrogen content varies widely according to the growth stage as reported by Faludi-Dàniel (1955). 
Measurements of these contents in different growth stages are very interesting. Experiments of this kind concerning the deficiency of alanine and leucine in both normals and chlorina are under way.

Acknowledgements. The authors beg to express their indebtedness to Dr. S. Matsumura for his encouragement. They are also greatly indebted to Dr. K. Hayashi for his valuable suggestions.

\section{References}

Edelman, J., Shibko, S. I., and Keys, A. J. (1959): The role of the scutellum of cereal seedlings in the synthesis and transport of sucrose, Jour. Exp. Bot., 10, 179-189.

Faludi-Dàniel, A. (1955): Changes in the organic-acid and amino-nitrogen contents of peas and maize during germination, Acta Bot. Acad. Sci. Hungaricae, 2, 243-251.

Fujii, T. (1955): Mutations in einkorn wheat induced by X-rays. I, Proc. Japan Acad., 31, 88-92.

- (1956): Idem. II, ibid., 32, 494-499.

Holmgren, P. (1956): Some observations on the amount of protein and nonprotein nitrogen in two pigment mutations of barley, Kungl. Lantbrukshögskolans Annaler, 22, 353-357.

Mericle, L. W., and Mericle, R. P. (1959): Changes in amino acid content induced by the X-radiation of developing barley embryos, Genetics, 44, 526-527.

Schwarze, P. (1952): Beziehungen zwischen Eiweissspiegel, Peroxydasereaktion und Chlorophyllbildung, Naturwiss., 39, 501-502.

Tolbert, N. E. (1957): Photosynthesis, ed. Comar et al.: Atomic Energy and Agriculture, Washington, 97-110. 